\title{
Sirozlu hastalarda Child-Pugh evresine göre hepatit B virüs DNA seviyeleri
}

\author{
Hepatitis B virus DNA levels according to the Child-Pugh stage in patients with cirrhosis
}

\author{
Arife Zühal DEĞIRMENCIOĞLU1', Yüksel SEÇKIN² \\ Department of Internal Medicine, Niğde Ömer Halisdemir University, School of Medicine, Niğde \\ Department of Gastroenterology, İnönü University, School of Medicine, Malatya
}

Giriş ve Amaç: Hepatit B virüsü nedeniyle siroz gelişen hastalarda Child-Pugh evresine göre HBV DNA düzeylerini karşılaştırmak. Gereç ve Yöntem: Retrospektif olarak yapılan bu çalışmaya hepatit B enfeksiyonu nedeniyle yeni siroz tanısı alan hastalar dahil edildi. Hepatit $B$ virus DNA, albümin, bilirübin ve uluslararası normalleştirilmiş oran düzeyleri Child-Pugh Skorlarına göre karşılaştıııldı. Bulgular: Çalışmaya ortalama yaşları 52.22 \pm 9.42 olan 90 hasta (60 erkek, 30 kadın) dahil edildi. Her grup 30 hastadan oluşuyordu. Hepatit DNA seviyesi, Grup A'da Grup B ve C'ye kıyasla anlamlı derecede düşüktü $(p=0.031)$. Gruplar arasında Child-Pugh skorları, albümin, bilirübin ve uluslararası normalleştirilmiş oran düzeyleri açısından anlamlı fark bulundu $(p=0.0001)$. Grup $B$ ve $C^{\prime}$ de albümin düzeyleri daha düşüktü ve uluslararası normalleştirilmiş oran düzeyleri daha yüksekti $(p<0.05)$. Asit ve ensefalopati $42(\% 46,7)$ ve $79(\% 87,8)$ hastada tespit edildi. C grubunda hem asit hem de ensefalopati daha sık görüldü. Sonuç: Hepatit B enfeksiyonu nedeniyle HBV DNA seviyesi sirozun erken evrelerinde belirgin olarak daha düşüktü ve albümin ve bilirübin düzeyleri nispeten normaldi. Ancak, kronik hepatit B'nin sonraki evrelerinde (Child-Pugh B ve C) asit ve ensefalopati daha sıktır, bilirübin ve hepatit $B$ düzeyleri artmakta ve albümin seviyeleri azalmaktadır.

Anahtar kelimeler: Hepatit B virüsü DNA, siroz, karaciğer yetmezliği, albümin, bilirübin, Child-Pugh Skoru

\section{INTRODUCTION}

Serum hepatitis B virus (HBV) DNA level has been previously shown to be an important and independent risk factor for the disease progression in chronic hepatitis B (1). Case-control and cohort studies have already shown that there is a significant dose-response relationship between serum HBV DNA levels measured at baseline and subsequent cirrhosis risk. Likewise, a similar relationship has been shown for the risk of hepatocellular carcinoma (HCC) (1-5). A strong correlation between the disease
Background and Aims: To compare hepatitis B virus DNA levels according to Child-Pugh stage in patients who developed cirrhosis due to hepatitis B virus. Materials and Methods: This study was conducted as retrospectively. Patients who were newly diagnosed with cirrhosis due to hepatitis $B$ virus infection were included. hepatitis $B$ virus DNA, albumin, bilirubin, and international normalization rate levels were compared according to the Child-Pugh Scores. Results: A total of 90 patients (60 males, 30 females) with a mean age of 52.22 \pm 9.42 years were included in this study. Each group consisted of 30 patients. Hepatitis $B$ virus DNA level was significantly lower in the Group A compared with the Group $B$ and $C(p=0.031)$. A significant difference was observed between the groups in terms of Child-Pugh scores, albumin, bilirubin, and international normalization rate levels (all $p=0.0001$ ). Albumin levels were lower and international normalization rate levels were higher in the Group $B$ and $C$ (all $p<0.05$ ). Ascites and encephalopathy were detected in $42(\% 46,7)$ and $79(87,8)$ patients, respectively. Both ascites and encephalopathy were more common in the Group C. Conclusion: Hepatitis B virus DNA level was significantly lower and albumin and bilirubin levels were relatively normal in the early stages of cirrhosis due to hepatitis B virus infection. By contrast, ascites and encephalopathy were more common, bilirubin and international normalization rate levels were elevated, and albumin levels were lower in the later stages (Child-Pugh B and C) of chronic hepatitis B.

Key words: Hepatitis B virus DNA, cirrhosis, liver failure, albumin, bilirubin, Child-Pugh Score

activity index in liver biopsy and serum HBV DNA levels as well (4). From this point of view, we believe that determining the HBV DNA level is of paramount importance in terms of disease activity, determination of prognosis, and planning of the management. Therefore, the objective of this study was to compare HBV DNA levels according to Child-Pugh stage in patients who developed cirrhosis due to hepatitis $B$ virus infection.

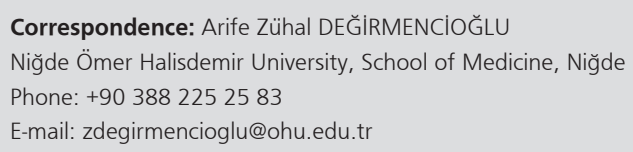

Manuscript: 28.09.2017 - Accepted: 02.04.2018 


\section{MATERIALS and METHODS}

\section{Study Design and Participants}

This study was conducted as retrospectively. Patients who had been followed due to Hepatitis B related cirrhosis in Inonu University Medical Faculty Turgut Özal Medical Center were included. All of the patients had previously undergone liver biopsy and/or clinical/laboratory findings and cirrhosis. Newly diagnosed patients were included. Patients who previously received medical treatment for the Hepatitis B infection were excluded.

\section{Assessments and Measurements}

The liver functional reserve was determined according to the Child-Pugh classification. Child-Pugh score and classification were assessed considering for ascitesand hepatic encephalopathy presence and grade, bilirubin, albumin and international normalization rate (INR) values.

Hematological and biochemical values and etiological factors were obtained by file scanning method. Ascites presence was determined with ultrasonographic imaging and classified as absent or present (mild, moderate, and diffuse). Routine biochemical analyzes and INR of the patients were measured by clotting method with the STA Compact brand of device and routine biochemical studies were carried out with the Olympus AU 600 analyzer by nephelometric method. High Pure Viral Nucleic Acid Kit was used for HBV DNA measurements. HBV DNA viral load was determined by Real Time PCR method using TaqMan probe.

\section{Child-Pugh Score}

The Child-Pugh Score was used to estimate the severity of cirrhosis in all patients. The Child-Pugh Score consists of 5 clinical properties comprising total bilirubin, serum albumin, protrombin time (INR), ascites, and hepatic encephalopathy. Each item is scored 1 to 3 points. Overall Class $A, B$, and $C$ refers to the 5-6, 7-9, and $10-15$ points respectively (6). Group A, B, and C comprised Class A, B, and $C$ patients respectively.

\section{Statistical Analysis}

SPSS version 16 (SPSS Inc., Chicago, IL, USA) was used for the statistical analyses. Data were expressed as mean \pm s.d. or percentage. Normal distribution was checked with the Kolmogorov-Smirnov test. Categorical variables between the groups were compared with the Chi-square test or Fisher's exact test. Differences between the means of the groups were compared with One-way ANOVA. A $p$ value lower than 0.05 was accepted as significant.

Table 1. HBV DNA levels according to the Child-Pugh Scores $\mathrm{X} \pm \mathrm{SD}$ (IU/ml)

\begin{tabular}{|lll|}
\hline Groups & \multicolumn{1}{c}{ HBV DNA Levels } & p value \\
\hline Child-Pugh A & $4.929 .337 \pm 18.090 .228$ & \\
\hline Child-Pugh B & $5.325 .332 \pm 17.974 .422$ & 0,031 \\
\hline Child-Pugh C & $1.526 .155 \pm 4.212 .272$ & \\
\hline
\end{tabular}

Table 2. Child-Pugh scores and laboratory measurements

\begin{tabular}{|c|c|c|c|c|}
\hline & Mean \pm SD & Minimum & Maximum & $P$ value \\
\hline \multicolumn{5}{|l|}{ Bilirubin } \\
\hline A & $1,09 \pm 0,52$ & 0,50 & 2,60 & \\
\hline B & $2,16 \pm 1,72$ & 0,20 & 8,70 & 0,0001 \\
\hline C & $3,91 \pm 2,50$ & 0,80 & 12,0 & \\
\hline \multicolumn{5}{|l|}{ Albumin } \\
\hline A & $4,06 \pm 0,50$ & 3,20 & 5,30 & \\
\hline B & $3,09 \pm 0,60$ & 1,90 & 4,30 & 0,0001 \\
\hline C & $2,70 \pm 0,48$ & 1,90 & 3,70 & \\
\hline \multicolumn{5}{|l|}{ INR } \\
\hline A & $1,25, \pm 0,20$ & 0,90 & 1,84 & \\
\hline B & $1,62 \pm 0,84$ & 1,11 & 5,85 & 0,0001 \\
\hline C & $1,98 \pm 0,62$ & 1,09 & 4,00 & \\
\hline \multicolumn{5}{|c|}{ Child-Pugh Score } \\
\hline A & $5,23 \pm 0,43$ & 5,00 & 6,00 & \\
\hline B & $7,90 \pm 0,84$ & 7,00 & 9,00 & 0,0001 \\
\hline C & $10,80 \pm 1,09$ & 10,00 & 14,00 & \\
\hline
\end{tabular}




\begin{tabular}{|ccc|}
\hline \multicolumn{3}{|c|}{ Table 3. Presence of the ascites } \\
\hline \multicolumn{3}{|c|}{ Acid } \\
\hline Group & Negative N, (\%) & Positive N, (\%) \\
\hline A & $30(0)$ & $0(0)$ \\
\hline B & $9(30)$ & $21(70)$ \\
\hline C & $3(10)$ & $27(90)$ \\
\hline Total & $42(46,7)$ & $48(53,3)$ \\
\hline
\end{tabular}

Table 4. Presence of the hepatic encephalopathy

\begin{tabular}{|ccc|}
\hline \multicolumn{2}{c|}{ Encephalopathy } \\
\hline Group & Negative N, (\%) & Positive N, (\%) \\
\hline A & $30(100)$ & $0(0)$ \\
\hline B & $27(90)$ & $3(10)$ \\
\hline C & $22(73,3)$ & $8(26,7)$ \\
\hline Total & $79(87,8)$ & $11(12,2)$ \\
\hline
\end{tabular}

\section{RESULTS}

A total of 90 patients $(60 \mathrm{M}, 30 \mathrm{~F})$ with a mean age of $52,22 \pm 9,42$ years were included in this study. Each group consisted 30 patients as the follows;

- Group A: 18 M, 12 F, mean age of 50,66 $\pm 9,18$ years

- Group B: 22 M, 8 F, mean age of 50,56 $\pm 11,29$ years

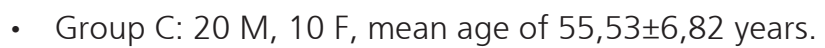

HBV DNA levels are shown in Table 1. A significant difference was observed between the groups $(p=0,031)$. HBV DNA level was significantly lower in the Group A compared with the Group B and C. However, no significant difference was observed between the Group B and C.

Child-Pugh scores, albumin, bilirubin, and INR levels are shown in Table 2. A significant difference was observed between the groups in terms of Child-Pugh scores, albumin, bilirubin, and INR levels (all $p=0,0001$ ). Ascites presence is shown in Table 3. Ascites was detected in 42 $(\% 46,7)$ patients. Encephalopathy presence is shown in Table 4. Both acid and encephalopathy were more common in the Group $C$.

\section{DISCUSSION}

In this study, we aimed to compare HBV DNA levels according to Child-Pugh stage in patients who develop cirrhosis due to hepatitis $B$ virus. Our analytic review have revealed four main findings;

i) HBV DNA level was significantly lower in the Group A.

ii) Ascites and encephalopathy were more common in the Group B and C.

iii) Bilirubin and INR levels were elevated in the Group B and $\mathrm{C}$.

iv) Albumin levels were lower in the Group B and C.

Child-Pugh classification, shows the degree of the liver failure, is the most important parameter to determine the prognosis in chronic hepatitis (6). Therefore we have used this classification in our study. High levels of HBV DNA indicate high viral replication. By contrast, low levels show the lower viral application. In this sense, determination of the HBV DNA level guides clinicians for the management $(3,4)$. Lu and colleagues (7) found no association between viral load and inflammatory activity and fibrosis grade in a study of 200 viral hepatitis patients (7). Besides, in a study conducted by Mohamadnejad and colleagues (8), HBV DNA levels were significantly reduced as the fibrosis progressed. In our study, in the Group C, we found that HBV DNA levels were significantly lower in cirrhotic patients. This may be due to a decrease in liver size and a decrease in hepatocyte mass.

Bilirubin,albumin levels and prothrombin time roughly reflect fibrosis grade and liver reserve (9). As the prothrombin activity decreases, prothrombin time and INR increases in chronic hepatitis patients. After cirrhosis, advanced fibrosis, is established, hypoalbuminemia as well as other laboratory findings such as increased bilirubin levels can be seen $(9,10)$. In our study, the INR level was mildly increased in the Group $A(1,25 \pm 0,20)$, yet the increase level was more prominent in the Group $C(1,98 \pm 0,62)$. Moreover, a significant difference was observed between the groups. Albumin levels decrease due to necroinflammation and fibrosis, and gamma-globulin increases in chronic liver diseases (11). Although there is no significant change in the synthesis of albumin at the beginning of chronic hepatitis, progression of fibrosis in the liver results in cirrhosis and decreased albumin synthesis. In a study done by Mohamadnejad et al. (8), albumin levels were studied in 276 patients with hepatitis B (229 patients with HBeAg negative hepatitis B) whereby low albumin levels were detected in patients with severe fibrosis. Hui et al (12) highlighted the fact that hypoalbuminemia is associated with increased fibrosis in their retrospective study consisting 235 patients. In our study, albumin levels were normal $(4,06 \pm 0,50 \mathrm{~g} / \mathrm{dl})$ in the Group A. Nonetheless, a mildly decrease $(3,09 \pm 0,60$ 
$\mathrm{g} / \mathrm{dl})$ and an apparent decrease $(2,70 \pm 0,48 \mathrm{~g} / \mathrm{dl})$ was detected in the Group C.

Generally, in acute and chronic hepatitis, bilirubin elevation is not known to be associated with the prognosis of the disease. The relationship between necroinflammation and bilirubin levels is not clearly explained. In advanced cirrhosis, hyperbilirubinemia may suggest a poor prognosis. In a retrospective study conducted by Hui et al. (12) in 235 chronic hepatitis B patients, elevated hyperbilirubinemia was associated with increased fibrosis. When the groups were compared in our study in terms of bilirubin, they were within normal range in the Group A $(1,09 \pm 0,52 \mathrm{mg} / \mathrm{dl})$ whereas increased in the Group B $(2,16 \pm 1,72 \mathrm{mg} / \mathrm{dL})$ and $C(3,91 \pm 2,50 \mathrm{mg} / \mathrm{dL})$.

Another important finding in our study was the increased rate of ascitesand encephalopathy levels in the Group
$B$ and $C$. This fact could be attributed to the increased fibrosis and advanced stages of the liver failure. Ascites or encephalopathy were not detected in any patient in the Group A. Therefore we once again highlight the early diagnosis of chronic hepatitis B infection in the early stages.

We have some important drawbacks for this study. First, this study was conducted as retrospectively. Second, lack of comorbidities was a limitation.

In the light of our results, HBV DNA level was significantly lower and albumin and bilirubin levels were relatively normal in the early stages of cirrhosis due to hepatitis B infection. By contrast, ascites and encephalopathy were more common, bilirubin, INR levels were elevated, and albumin levels were lower in the later stages (Child-Pugh $B$ and $C$ ) with chronic hepatitis $B$.

\section{REFERENCES}

1. Kim SE. Quantitative hepatitis B surface antigen predicts the antiviral response and hepatocellular carcinoma development in patients with chronic hepatitis B. Korean J Int Med 2017;32:631-3.

2. Polish Group of Experts for HBV, Flisiak R, Halota W, et al. Recommendations for the treatment of hepatitis B in 2017. Clin Exp Hepatol 2017;3:35-46.

3. Chen CJ, lloeje UH, Yang HI. Long-term outcomes in hepatitis B: the REVEAL-HBV study. Clin Liver Dis 2007;11:797-816.

4. Chen CJ. Global elimination of viral hepatitis and hepatocellular carcinoma: opportunities and challenges. Gut. 2018 doi: 10.1136/ gutnl-2017-315407. Epub 2018 Jan 24.

5. Ringehan M, McKeating JA, Protzer U. Viral hepatitis and liver cancer. Philos Transac R Soc Lond B Biol Sci. 2017; 372: 20160274. Erratum in: Philos Trans R Soc Lond B Biol Sci 2018;373.

6. Gür G. Karaciğer Transplantasyonu. In: Özden A, Şahin B, Yılmaz U, Soykan I. Gastroenteroloji 1. Basım. Türk Gastroenteroloji Vakfı 2002;672-3.

7. Lu LG, Zeng MD, Mao YM, et al. Relationship between clinical and pathologic findings in patients with chronic liver diseases. World J Gastroenterol 2003;9:2796-800.

8. Mohamadnejad M, Montazeri G, Fazlollahi A, et al. Noninvasive markers of liver fibrosis and inflammation in chronic hepatitis B-Virus related liver disease. Am J Gastroenterol 2006;101:2537-45.

9. Afdhal $\mathrm{NH}$, Nunes D. Evaluation of liver fibrosis: a concise review. Am J Gastroenterol 1999;6:1160-74.

10. Halfon $P$, Bourlière $M$, Pénaranda $G$, et al. Accuracy of hyaluronic acid level for predicting liver fibrosis stages in patients with hepatitis C virus. Comp Hepato 2005;11:6.

11. Schmilovitz-Weiss $H$, Tovar A, Halpern $M$, et al. Predictive value of serum globulin levels for the extent of hepatic fibrosis in patients with chronic hepatitis B infection. J Viral Hepat 2006;13:671-7.

12. Hui AY, Chan HL-Y, Wong VW-S, et al. Identification of chronic hepatitis B patients without significant liver fibrosis by a simple noninvasive predictive model. Am J Gastroenterol 2005;100:61623. 